\title{
Depremleri Anlamlandırma ve Açıklama Biçimlerinin Risk Azaltma Süreçlerine Etkisi Açısından 2011 Van Depremleri ${ }^{1}$
}

\author{
Mehmet Baki BíLIK ${ }^{2 *}$
}

\section{Öz}

Depremlerin nedeni bilimsel olarak izah edilmediği dönemlerde, bu "korkunç" olay günahların bedeli, ihtar veya benzer mistik, metafizik süreçlerle açıklanmaktaydı. Neyse ki bilimsel gelişmelerle beraber depremlerin hangi süreçlerle oluştuğunu çağımızda izah edebilmiş bulunmaktayız. Fakat bilimsel izahlara rağmen depremler bazı kesimler için hala mistik süreçlerin bir ürünü, yaratıcının bir cezası olarak yorumlanabilmektedir. Nerede, ne zaman ve ne şiddette olacağı hala kestirilemeyen depremlerin yarattığı kaos, ardından bıraktığı ölüm, yıkım ve gözyaşları insanların bu olayı irrasyonel süreçlerle açıklamaya zorlayabilmektedir. Depremleri doğaüstü süreçlerle açıklayanlar yaşanılanları kader kabul edip, maddi koşullarıyla bu tehlikeye karşı direnme pratiğinden de vazgeçebilmektedirler. İrrasyonel bir tehdide cevap da irrasyonel olabilmekte dolaysıyla ahlaksızlığın veya günahların karşılığı olan depremlerden korunmanın yolu da pekâlâ günah işlememek veya yaratıcının buyruklarına itaat etmekle mümkün görülür. Nihayetinde depremi anlama, açıklama biçimi beraberinde baş etme pratiği de doğurmaktadır. Bu araştırma, tüm bu süreçleri 2011 Van Depremleri'ne maruz kalmış bireyler üzerinden test etmektedir. Depreme maruz kalmış 225 kişinin bu olayı anlama ve anlamlandırma süreçleri ile hazırlık durumlarını sosyoekonomik özellikleri üzerinden değerlendirmektedir. Yapılan tespitlerde sosyoekonomik özelliklerin depremi ampirik süreçlerle açıklama veya anlamlandırma mekanizmaları üzerinde etkili olduğu gözlenmiştir. Benzer şekilde depreme risk azaltma çalışmaları ile katılımcıların gelir düzeyleri arasında anlamlı bir ilişki görülmüştür.

Anahtar Kelimeler: Deprem, Anlamlandırma/Atfetme, Risk Azaltma, Van Depremi.

\section{Van Earthquakes in 2011: On The Impacts of Explaning Earthquakes on Risk Mitigation Processes}

\begin{abstract}
In times when the cause of earthquakes was not scientifically explained, this "terrible" event was explained by the price of sins, caution, or similar mystical, metaphysical processes. Fortunately, with scientific developments, we are able to explain the processes of earthquakes in our age. However, despite scientific explanations, for some, earthquakes can still be interpreted as a product of mystical processes and as a punishment. The chaos created by the unpredictable earthquakes, the death, destruction and tears can force people to explain this event through irrational processes. Those who explain earthquakes through supernatural processes can accept the experiences as fate and give up resisting this danger with their material conditions. The answer to an irrational threat can also be irrational, so the way to protect from immorality or earthquakes that is the price of sins is also possible by not

\footnotetext{
${ }^{1}$ Bu araştırmanın verileri, 2011 Van Depremleri Üzerine Sosyolojik Bir Analiz, Mekân, Afet Yönetimi ve Algı adlı yüksek lisans tezinden alınmıştır.

${ }^{2}$ Yüzüncü Yıl Üniversitesi, Sosyoloji Bölümü, Van.

* Ilgili Yazar/Corresponding author: bilikmb@gmail.com 
sinning or obeying the creator's commandments. In the end, understanding and explaining the earthquake leads to the practice of coping with it. This research tests all these processes on individuals exposed to the 2011 Van Earthquakes. It also discusses 225 people's, all experienced earthquakes, understanding and explaining processes of the event and their preparedness status within the scope of their socioeconomic characteristics. The findings showed that socioeconomic characteristics had an impact on the mechanisms of explaining or interpreting the earthquake through empirical processes. Similarly, a significant correlation was found between earthquake risk reduction studies and income levels of the participants.

Key Words: Earthquake, Explaining/Attribution, Risk Reduction, Van Earthquake.

\section{GiRiş}

Doğa olaylarının net olarak bilinmediği dönemlerde deprem gibi korkutucu sırları içerisinde barındıran büyük felaketler, yoldan çıkmış insanları bir tür cezalandırma ve terbiye etme aracı olarak algılanmıştır. İnsanlar rutin yaşantılarını birdenbire kaosa dönüştüren; sevdiklerini, mallarını kendilerinden alan bu sarsıcı felaketleri uzun süre doğaüstü güçlerle açıklamışlardır(Kasapoğlu, 2001: 6). Sismik bölgelerde kurulmuş eski medeniyetlerde, depremleri doğaüstü güçlerle açıklayan efsanelerin (Duman, 2016: 39-41) günümüze kadar ulaşması aslında bu anlama açıklama ihtiyacının tezahürleridir. Günümüzde dahi artan bilimsel açıklamalara rağmen hala kimi insanlar için deprem, anlaması ve açıklanması zor metafizik süreçlerin ürünüdür. Bu doğa olayını farklı referanslarla açıklayanların yanı sıra her iki açıklamaya aynı anda başvurabilen eklektik anlama ve açıklama biçimlerine de rastlanmaktadır (Köse ve Küçükcan, 2006: 152).

Depremi anlamlandırma ve açıklama biçimlerinin beraberinde bu tehlikeye karşı önceden önlem alma süreçlerini ne düzeyde etkilediği ise bir diğer merak konusudur. Başka bir ifadeyle depremleri baş edilmesi zor, doğaüstü hadiseler olarak görenler ile yaşanılanları ampirik süreçlerle açıklayıp anlamlandıranların önlem alma, hazırlık yapma veya risk azaltma süreçleri benzer midir? Nitekim Giddens'a göre riskin geleneksel toplumlarda bir karşılığı yoktur. Modern toplum bireyi geleceğini dine, geleneğe veya metafizik süreçlere bırakmak yerine kendisinin belirlemeye çalışır. Bu anlamda modern insan, tehlike ve risk olasılıklarını hesaplayarak, bilinmeyen süreçleri bilinir kılmaya çalışır (Giddens, 1994: 36-39). Bu araştırma bu sorunun peşinde 2011 Van Depremlerini yaşamış kişilerin sosyoekonomik özellikleri üzerinden depremleri atfetme/anlamlandırma süreçlerine bakmakta, ardından kişilerin depremleri atfetme biçimleri ile risk azaltma pratikleri arasındaki ilişkiyi anlamaya çalışmaktadır. $\mathrm{Bu}$ açıdan hem risk azaltma süreçleri hem de depremleri anlamlandırma/atfetme süreçlerine dair literatüre ayrı ayrı bakılmıştır.

İnsanlar yaşadıkları hayat ve evrenin varlığı başta olmak üzere, çevrelerinde meydana gelen olayları sürekli anlamlandırma eğiliminde oldukları görülmektedir. Bu durum Aristo'nun ifadesiyle tüm insanların doğaları gereği bilmeyi arzulamalarından kaynaklanır. Bu anlama ve bilme isteği, Dewey'de "kesinliği arama", Maslow'da "bilme ve anlama arzusu" Frankl'de "anlam arayışı" olarak ifade bulmuştur(Spilka ve diğerleri, 1985: 4).

Anlam arayışı insanın doğuştan sahip olduğu bir eğilim olup, kişinin inancına, kontrol duygusuna veya özsaygısına yapılan bir tehdit durumunda bir savunma görevi görmektedir. $\mathrm{Bu}$ durum kişiye gelecekteki olaylara katlanabilme açısından da garanti vermektedir. Ayrıca olayların olumsuz yönlerinin yanında olumlu yönlerini de görme eğilimi veren atfetme süreci, kişide yaşanılanların tesadüfi olmadığını aksine bir planın parçası olduğuna dair inancı aşılamaktadır. Spilka'ya (1985) göre insanların iç ve dış dünyasını tehdit eden olayları ve olguları (doğal afetler, ölümler, hastalıklar vb.) açıklama ve anlamlandırma biçimlerine yönelik üç önemli dürtü vardır. Bunlar; insanlar yaşadıkları olayları bir mana içerisinde 
anlama ve açıklama isteği, gelecekte olacakları kontrol etme konusunda öngörülere sahip olma isteği ve öz-saygısını koruma ve sürdürme isteğidir. Kişinin çocukluğundan itibaren aldığı eğitim, içinde yetiştiği toplumun dini atmosferi, büyüdüğü aile ortamı gibi faktörler bu yönüyle algılama ve anlamlandırma süreçlerinde belirleyicidir. Dinsel değerlerin baskın olduğu bir ailede yetişen veya dinsel kültürün belirleyici olduğu bir toplumdan gelen bireyin anlamlandırmaları din yüklüyken, dine ilgisi zayıf veya tamamen ilgisiz olan bir çevrede büyümüş insanların dindar insanlara oranla algılama ve anlamlandırmaları daha seküler nitelikte olabilmektedir(Spilka ve diğerleri, 1985: 5)

İnsanlar deprem gibi kontrolü kendi güçlerini aşan durumlarda da benzer bir anlam arayışına girerler. Bu anlamlandırma sürecinde rasyonel izahla işin içinden çıkamayan bireyin yardımına genellikle dini inanç sistemleri koşar. Kompleks veya çelişik görünen durumlar metafizik süreçlerle izah edilir ve böylece birey yaşadığı gerilimden kurtulur. Elbette bu mekanizmada bireyin eğitim düzeyi, zihinsel anlamda beslendiği kaynaklar ve özellikle de içinde büyüdüğü psikososyal çevrenin etkisi büyüktür.

Gerek Kula (2002) gerekse de Köse ve Küçükcan'ın (2006) 1999 Marmara depreminden sonra yaptıkları araştırmalar, dinin anlamlandırma ve başetme sürecinde önemli bir kaynak olduğunu göstermiştir. Din, anlam arayışı bağlamında insanları belirsizlik duygusundan kurtularak özgüvenlerini tekrar sağlamalarında yardımcı olduğu; Allah ve ahiret inancı ile kayıpların kabullenmesini kolaylaştığı, felaketzedelere iyimserlik ve umut gibi ruh sağlığı açısından olumlu duygular kazandırdığı gözlenmiştir (Köse ve Küçükcan, 2006: 140). Benzer şekilde Kula tarafından 1999 Marmara depreminden sonra yapılan bir araştırmada depremzedelerin \%76'sının deprem esnasında çeşitli dini davranışlara başvurdukları gözlenmiştir. Aynı araştırmacı tarafından benzer bir araştırma Düzce Depremi'nden sonrada yapıımış; bu çalışmada da afetzedelerin yaşadıkları korku ve acıyı hafifletmek için bir takım dinsel pratikler geliştirdikleri, ibadete başladıkları gözlenmiştir (Kula, 2002: 242; User, 2006: 39).

Anlamlandırma/atfetme süreçlerinin beraberinde risk azaltma pratiklerini ne düzeyde etkilediğine dair literatürde yakın zamanda yapılmış herhangi bir çalışmaya rastlanmazken bu sürecin depremlerle başetme pratiğini etkilemesi aslında beklenen bir durumdur. Çünkü depremi metafizik süreçlerle açıklama gayretinde olanların kapsamlı bir risk azaltma pratiği yerine, kaderine razı bir tutum sergilemeleri ve dua, ibadet gibi daha mistik başetme süreçlerine başvurmaları beklenen bir durumdur. Nitekim depremin doğaüstü süreçlerle açıklandığı dönemlerde insanların, dua, ibadet, adak vb. başetme pratikleri geliştirdiklerine dair literatürde birçok örneğe rastlanmaktadır(Vercleyen, 1997; Dynes, 1999; Arslantaş, 2003; Akyel, 2007).

Türkiye'de toplumun risk azaltma konusunda hala istenilen düzeyde olmamasının altında hangi saiklerin yattığını anlamaya çalışmak özellikle toplumu depremlere hazırlamak açısından önemlidir. Araştırmalar depreme hazırlık süreçlerinin hala yeterli düzeyde olmadığını göstermektedir. Karancı ve arkadaşlarının Erzincan, Dinar ve Çankırı'da farklı tarihlerde yaptıkları araştırmalarda insanların sadece \%2 ile \%30'unun deprem çantası hazırlama, konutunu sağlamlaştırma, yiyecek-giysi stoku ve deprem poliçesi yaptırma gibi çeşitli biçimlerdeki hazırlık çalışmalarına katıldıkları gözlenmiştir (Karancı, 2008: 53). Yine AFAD tarafından yapılmış bir araştırmada, katılımcıların yalnızca \%10'unun afetlere karşı çeşitli hazırlıklar yaptığı görülmüştür. Aynı araştırmada hazırlık yapmayanların oranı $\% 43,6$ olarak tespit edilirken, kesinlikle hazırlıksız olduğunu belirtenlerin \%26,1 oranında olduğu gözlenmiştir (AFAD, 2014). Afyon'da yapılmış benzer bir çalışmada ise araştırmaya katılanların \%73,6'sının olası bir afet için önlem almadıkları görülmüştür (Koçak, 2004: 139). 
Risk azaltma süreçlerinde sosyoekonomik özelliklerin etkisini ölçen araştırmalarda da benzer sonuçlar dikkat çekmektedir. 1999 Büyük Marmara Depremi'nin ardından yapılan bir araştırmada sosyoekonomik özellikler ile risk azaltma çalışmalarına katılım arasında anlamlı bir ilişkinin olduğu gözlenmiştir. Araştırmada gelir seviyesi düşük olan grupların olası bir depreme karşı, gelir seviyesi yüksek gruplara oranla kendilerini daha az hazır hissettikleri tespit edilmiştir (Müderrisoğlu, 2008: 81-124). İstanbul Belediyesi için Kalaycıoğlu ve arkadaşlarının (2014) danışmanlığı etrafında yürütülen bir alan araştırmasında da benzer sonuçlar dikkat çekmektedir. Araştırmaya göre deprem konusundaki bilgi eksikliği düşük gelirli haneler arasında daha yaygındır. Benzer şekilde düşük gelire sahip grupların yarısından fazlası depreme hazırlık konusunda yetersiz bilgiye sahiptir (IBB, 2014: 39).

Sismik risk açısından zor bir coğrafyada kurulu olan Türkiye'nin, risk azaltma çalışmalarında toplumun isteksiz veya yavaş hareket etmesinin altında yatan faktörleri tespit etmek mevcut afet araştırmalarının belki de en can alıcı konularından birini oluşturmaktadır. Çünkü topraklarının \%92'si, nüfusunun da \%98'i deprem tehlikesi altında bulunan (Türkiye Büyük Millet Meclisi [TBMM], 2010: 12) Türkiye'nin her şiddetli depremde büyük kayıplar yaşanmasının nedeni yalnızca deprem tehlikesi gibi dışsal bir faktör olamaz. Bunda tecrübelerine rağmen her seferinde hazırlıksız yakalanan toplumun zarar görebilirliği ve buna yol açan bilişsel ve/veya bilişsel olmayan gerekçelerdir. Bu araştırma söz konusu bu gerekçeleri anlamak üzere toplumsal düzlemde risk azaltma süreçlerine katılım ile depremleri anlamlandırma/atfetme süreçleri arasındaki ilişkiyi ortaya koymayı amaçlamıştır. Bu bağlamda ilkin sosyoekonomik özellikler ile anlamlandırma/atfetme süreçleri arasındaki ilişki düzeyi ölçülmüş ardından anlamlandırma/atfetme biçimlerinin zarar azaltma süreçlerine etkisi ortaya koyulmuştur.

\section{ARAŞTIRMANIN METODOLOJI}

Araştırma verileri, 2011 yılında Van'da meydana gelen iki yıkıcı depreme maruz kalmış 225 katıımcıyla yapılan yüz yüze görüşmelere dayanmaktadır. Araştırmanın evrenini Van kent merkezi, örneklemini ise Van kent merkezindeki alt, orta ve üst sosyoekonomik özelliği temsilen seçilmiş üç farklı mahalle oluşturmaktadır. Örneklemi oluşturan mahalleler belirlenirken çeşitli kamu kurum ve kuruluşlarınca önceden oluşturulmuş sağlık sigortası, sosyal yardım alma oranları gibi çeşitli ön verilerden yararlanılmıştır.

Söz konusu mahallelerin öngörülen sosyoekonomik özellikleri karşılama yetenekleriyle ilgili olarak saha verilerine bakılmış; veriler ile örneklem grubunun temsil kabiliyetinin örtüştüğü görülmüştür. Örneğin alt gelir grubunu temsilen seçilen Hacıbekir Mahallesi'nin eğitim durumu, sahip olunan meslek, çocuk sayısı gibi göstergeler ile orta gelir grubunu temsil eden Ali Paşa Mahallesi ve üst gelir grubunu oluşturan Cumhuriyet Mahallesi'nin söz konusu özellikleri arasında anlamlı bir farklılığın olduğu gözlenmiştir. Araştırma kapsamında örneklem grubunu oluşturan her bir mahallenin sakinleriyle 75, toplamda 225 görüşme yapılmış ve elde edilen sonuçlar görüşmecilerin sosyoekonomik özellikleri eşliğinde yorumlanmıştır. Bulgular önce atfetme/anlamlandırma biçimleri ardından hazırlık yapma süreçleri şeklinde yorumlanıp karşılaştırılmıştır.

\section{BULGULAR}

Bulgular dört tablo üzerinden değerlendirilmiştir. Bu tabloların üçü depremi yaşamış bireylerin, depremi anlamlandırma/atfetme biçimlerini ortaya koymaktadır. Son tablo ise söz konusu bu bireylerin deprem riski azaltma süreçlerini yansıtmaktadır. 
Tablo 1: “Deprem bir kaderdir; Allah'ın insanlara uyarısıdır.” ifadesine yönelik verilen cevapların mahallelere göre dağılımı

\begin{tabular}{|c|c|c|c|c|c|c|c|c|}
\hline \multirow{2}{*}{\multicolumn{2}{|c|}{ Mahalle }} & \multicolumn{6}{|c|}{ Deprem bir kaderdir; Allah'ın insanlara uyarısıdır. } & \multirow{3}{*}{$\begin{array}{c}\text { Toplam } \\
75 \\
\end{array}$} \\
\hline & & \multirow{2}{*}{$\begin{array}{c}\text { Kesinlikle } \\
\text { Yanlış } \\
4 \\
\end{array}$} & \multirow{2}{*}{$\begin{array}{c}\begin{array}{c}\text { Çok } \\
\text { Yanlış }\end{array} \\
1 \\
\end{array}$} & \multirow{2}{*}{$\frac{\text { Yanlış }}{1}$} & \multirow{2}{*}{$\begin{array}{c}\text { Doğru } \\
11 \\
\end{array}$} & \multirow{2}{*}{$\begin{array}{c}\begin{array}{c}\text { Çok } \\
\text { Doğru }\end{array} \\
6 \\
\end{array}$} & \multirow{2}{*}{$\begin{array}{c}\begin{array}{c}\text { Kesinlikle } \\
\text { Doğru }\end{array} \\
52 \\
\end{array}$} & \\
\hline Hacıbekir & Sayı & & & & & & & \\
\hline Mahallesi & $\%$ & 5,3 & 1,3 & 1,3 & 14,7 & 8,0 & 69,3 & 100 \\
\hline \multirow{2}{*}{$\begin{array}{l}\text { Ali Paşa } \\
\text { Mahallesi }\end{array}$} & Sayı & 2 & 0 & 4 & 15 & 2 & 52 & 75 \\
\hline & $\%$ & 2,7 & 0 & 5,3 & 20 & 2,7 & 69,3 & 100 \\
\hline \multirow{2}{*}{$\begin{array}{l}\text { Cumhuriyet } \\
\text { Mahallesi }\end{array}$} & Sayı & 13 & 0 & 2 & 18 & 6 & 36 & 75 \\
\hline & $\%$ & 17,3 & 0 & 2,7 & 24 & 8,0 & 48,0 & 100 \\
\hline \multirow{2}{*}{ Toplam } & Sayı & 19 & 1 & 7 & 44 & 14 & 140 & 225 \\
\hline & $\%$ & 8,4 & 0,4 & 3,1 & 19,6 & 6,2 & 62,2 & 100 \\
\hline
\end{tabular}

Araştırmaya konu olan afetzedelerin, "Deprem bir kaderdir; Allah'ın insanlara uyarısıdır" ifadesine dönük yanıtları incelenmiştir. Araştırmaya katılan afetzedelerin \%62,2'si bu ifadeye "Kesinlikle Doğru" yanıtı verirken, \%6,2'si çok doğru ve \%19,6'sı ise doğru yanıtını vermiştir. Kesinlikle yanlış diyenlerin oranı $\% 8,4$, çok yanlış ve yanlış diyenlerin toplam oranı ise \%3,5'tir. Genel olarak bakıldığında araştırmaya katılan afetzedelerin \%88'i depremin bir kader olduğu ve bir uyarı niteliği taşıdığı fikrinde birleşmektedir.

Mahallelere göre dağılıma bakıldığında örneklem grubunda yüksek sosyoekonomik özellikteki afetzedeleri temsil eden Cumhuriyet Mahallesi katılımcılarının \%80'ni depremin bir kader olduğunu düşünmektedir. Orta düzey sosyoekonomik özelliklere sahip afetzedeleri temsil edildiği Ali Paşa'da bu oran \%92 ve alt düzey sosyoekonomik özellikteki afetzedeleri temsil edildiği Hacıbekir Mahallesi'nde ise \%92'lik bir oranla önerme desteklenmiştir. Yanıtlar bir arada yorumlandığında, araştırmaya katılan afetzedelerin büyük bir çoğunluğunun depremin bir kader olduğu ve Allah'ın insanlara birer uyarısı olduğu konusunda hemfikir oldukları görülmüştür. Sosyoekonomik özellikler açısından karşılaştırdığımızda üst sosyoekonomik özellikteki Cumhuriyet Mahallesi sakinlerinin nispeten diğerlerinden ayrıştığını görmekteyiz.

Tablo 2. "Depremin sebebi toplumdaki ahlaksızlıkların artmasıdır." ifadesine yönelik verilen cevapların mahallelere göre dağılımı

\begin{tabular}{|c|c|c|c|c|c|c|c|c|}
\hline \multirow{2}{*}{\multicolumn{2}{|c|}{ Mahalle }} & \multicolumn{6}{|c|}{ Depremin sebebi toplumdaki ahlaksızlıkların artmasıdır. } & \multirow{3}{*}{$\begin{array}{c}\text { Toplam } \\
75\end{array}$} \\
\hline & & \multirow{2}{*}{$\begin{array}{c}\begin{array}{c}\text { Kesinlikle } \\
\text { Yanlış }\end{array} \\
10\end{array}$} & \multirow{2}{*}{$\begin{array}{c}\begin{array}{c}\text { Çok } \\
\text { Yanlış }\end{array} \\
1\end{array}$} & \multirow{2}{*}{$\frac{\text { Yanlış }}{4}$} & \multirow{2}{*}{$\begin{array}{c}\text { Doğru } \\
21\end{array}$} & \multirow{2}{*}{$\begin{array}{c}\begin{array}{c}\text { Çok } \\
\text { Doğru }\end{array} \\
10\end{array}$} & \multirow{2}{*}{$\begin{array}{c}\begin{array}{c}\text { Kesinlikle } \\
\text { Doğru }\end{array} \\
29\end{array}$} & \\
\hline Hacıbekir & Sayı & & & & & & & \\
\hline Mahallesi & $\%$ & 13,3 & 1,3 & 5,3 & 28 & 13,3 & 38,7 & 100 \\
\hline \multirow{2}{*}{$\begin{array}{l}\text { Ali Paşa } \\
\text { Mahallesi }\end{array}$} & Sayı & 11 & 1 & 7 & 18 & 5 & 33 & 75 \\
\hline & $\%$ & 14,7 & 1,3 & 9,3 & 24 & 6,7 & 44 & 100 \\
\hline \multirow{2}{*}{$\begin{array}{l}\text { Cumhuriyet } \\
\text { Mahallesi }\end{array}$} & Sayı & 24 & 4 & 11 & 20 & 1 & 15 & 75 \\
\hline & $\%$ & 32 & 5,3 & 14,7 & 26,7 & 1,3 & 20 & 100 \\
\hline \multirow{2}{*}{ Toplam } & Sayı & 45 & 6 & 22 & 59 & 16 & 77 & 225 \\
\hline & $\%$ & 20 & 2,7 & 9,8 & 26,2 & 7,1 & 34,2 & 100 \\
\hline
\end{tabular}

Depremlerden sonra tartışılan önemli konulardan biride bu tür felaketlere doğal nedenlerin dışında başka nedenlerin aranmasıdır. Katılımcıların bu konudaki tutumlarını ölçmek üzere "Depremin sebebi toplumdaki ahlaksızlıkların artmasıdır" önermesine verdikleri yanıtlar sorgulanmıştır. Araştırmaya katılan afetzedelerin \%67,5'i bu fikri desteklerken, \%32,5'i bu görüşe katılmadığını beyan etmiştir. Mahalleleri karşılaştırdığımızda Hacıbekir Mahallesi'nden araştırmaya katılanların \%80'ni depremin sebebi olarak ahlaksızlıkların artışını görürken, Ali Paşa'da bu oran \%74,7, Cumhuriyet'te ise \%48 olarak gerçekleşmiştir. 
Sosyoekonomik özellikler açısından oranlar karşılaştırıldığında net bir ayrışma olduğu görülmektedir. Sosyoekonomik düzey düştükçe depremi ahlaksızlıklara yorma oranının artığı gözlenmektedir. Diğer bir ifadeyle sosyoekonomik düzey bireylerin depremi doğal süreçlerle veya bu süreçlerin dışında bir nedenle anlamlandırma, açıklama çabalarını etkilemektedir.

Tablo 3. "Depremden sonra kendimi daha dindar hissediyorum." ifadesine yönelik verilen cevapların mahallelere göre dağılımı

\begin{tabular}{|c|c|c|c|c|c|c|c|c|}
\hline \multirow{2}{*}{ Mahalle } & & \multicolumn{6}{|c|}{ Depremden sonra kendimi daha dindar hissediyorum. } & \multirow[b]{2}{*}{ Toplam } \\
\hline & & $\begin{array}{c}\text { Kesinlikle } \\
\text { Yanlış }\end{array}$ & $\begin{array}{c}\text { Çok } \\
\text { Yanlış }\end{array}$ & Yanlış & Doğru & $\begin{array}{c}\text { Çok } \\
\text { Doğru }\end{array}$ & $\begin{array}{l}\text { Kesinlikle } \\
\text { Doğru }\end{array}$ & \\
\hline \multirow{2}{*}{$\begin{array}{l}\text { Hacıbekir } \\
\text { Mahallesi }\end{array}$} & Sayı & 8 & 3 & 13 & 16 & 6 & 29 & 75 \\
\hline & $\%$ & 10,7 & 4,0 & 17,3 & 21,3 & 8 & 38,7 & 100 \\
\hline \multirow{2}{*}{$\begin{array}{l}\text { Ali Paşa } \\
\text { Mahallesi }\end{array}$} & Sayı & 14 & 2 & 19 & 19 & 6 & 15 & 75 \\
\hline & $\%$ & 18.7 & 2.7 & 25,3 & 25,3 & 8 & 20 & 100 \\
\hline \multirow{2}{*}{$\begin{array}{l}\text { Cumhuriyet } \\
\text { Mahallesi }\end{array}$} & Sayı & 18 & 0 & 21 & 17 & 5 & 14 & 75 \\
\hline & $\%$ & 24 & 0 & 28 & 22,7 & 6,7 & 18,7 & 100 \\
\hline \multirow{2}{*}{ Toplam } & Sayı & 40 & 5 & 53 & 52 & 17 & 58 & 225 \\
\hline & $\%$ & 17,8 & 2,2 & 23,6 & 23,1 & 7,6 & 25,8 & 100 \\
\hline
\end{tabular}

Afetzedelere depremden sonra dine yönelme düzeylerini ölçmek üzere yöneltilen "Depremden sonra kendimi daha dindar hissediyorum" önermesine verilen yanıtların sosyoekonomik özelliklerle doğru orantıda olduğu saptanmıştır. Elde edilen sonuçlara göre katılımcıların \%56,5’i depremden sonra kendisini daha dindar hissettikleri gözlenmiştir. Mahallelere göre oranlar değerlendirildiğinde Hacıbekir Mahallesi'nden katılan afetzedelerin \%68'i depremden sonra kendisini daha dindar hissettiğini söylerken, Ali Paşa'da bu oran $\% 53,3$, Cumhuriyet'te ise \%48,1 olarak gerçekleşmiştir. Bir önceki tabloda gösterilen sonuçları destekler nitelikte bu tabloda da düşük sosyoekonomik özellikteki insanların yüksek sosyoekonomik özellikteki insanlara oranla afet dönemlerinde dine daha fazla yöneldiği gözlenmiştir. Yaşanılan afet sürecini dini referanslarla açıklama davranışı ile sosyoekonomik özellikler arasında anlamlı bir ilişkinin varlığı dikkat çekmektedir.

Aynı görüşme diliminde afetlerin depreme hazırlık yapma düzeyleriyle ilgili olarak 6 soru yöneltilmiş ve gelen yanıtlar sosyoekonomik özellikleri temsilen mahallelere göre Tablo 4'te yorumlanmıştır.

Tablo 4. Risk azaltma düzeylerinin mahallelere göre dağılımı

\begin{tabular}{|l|c|c|c|c|c|c|}
\hline \multirow{2}{*}{ Risk Azaltma Düzeyleri } & \multicolumn{2}{|c|}{ Hacıbekir } & \multicolumn{2}{c|}{ Ali Paşa } & \multicolumn{3}{c|}{ Cumhuriyet } \\
\cline { 2 - 7 } & Evet & Hayır & Evet & Hayır & Evet & Hayır \\
\hline Deprem Sigortası (DASK) yaptırdınız mı? & $\% 6$ & $\% 94$ & $\% 24$ & $\% 76$ & $\% 16$ & $\% 84$ \\
\hline Eviniz eşyalarını sabitlediniz mi? & $\% 17,3$ & $\% 82,7$ & $\% 16$ & $\% 84$ & $\% 22,7$ & $\% 77,3$ \\
\hline Deprem çantası hazırladınız mı? & $\% 6,7$ & $\% 93,3$ & $\% 99,3$ & $\% 90,7$ & $\% 18,7$ & $\% 81,3$ \\
\hline Evin en güvenilir yerini tespit ettiniz mi? & $\% 14,7$ & $\% 85,3$ & $\% 32$ & $\% 68$ & $\% 30,7$ & $\% 69,3$ \\
\hline $\begin{array}{l}\text { Depremi yaşamadan önce olası bir deprem anında } \\
\text { neler yapılması gerektiğiyle ilgili bir bilginiz var } \\
\text { mıydı? }\end{array}$ & $\% 14$ & $\% 86$ & $\% 28$ & $\% 72$ & $\% 40$ & $\% 60$ \\
\hline $\begin{array}{l}\text { 2011 Depremleri öncesinde Van'ın deprem bölgesi } \\
\text { olduğunu biliyor muydunuz? }\end{array}$ & $\% 42$ & $\% 58$ & $\% 66$ & $\% 34$ & $\% 70$ & $\% 30$ \\
\hline
\end{tabular}


Tablodaki sorulara gelen yanıtlar sırasıyla değerlendirildiğinde deprem sigortası yaptırma oranı ile sosyoekonomik özellikler arasında nispeten doğru orantı olduğu gözlenmektedir. En az sigorta yaptıranlar düşük sosyoekonomik özellikteki Hacıbekir Mahallesi'nde \%6 oranındayken orta gelir grubunu temsil eden Ali Paşa'da bu oran \%24, üst gelir grubunu temsil eden Cumhuriyet Mahallesi'nde ise \%16 olarak tespit edilmiştir. Evdeki eşyaları sabitleme ve deprem çantası hazırlama sorularına verilen yanıtlar karşılaştırıldığında sosyoekonomik düzeyi yüksek katılımcıları temsilen seçilen Cumhuriyet Mahallesi katılımcıların \%22'sinin evdeki eşyalarını sabitledikleri buna karşın sosyoekonomik düzeyi düşük katılımcıları temsil eden Hacıbekir Mahallesi'nde \%17,3 ile sınırlı kaldığı görülmektedir. Benzer şekilde Cumhuriyet Mahallesi'ndeki katılımcıların \%18,7'si deprem çantası hazırlarken, bu oran Hacıbekir Mahallesinde yalnızca \%6,7'dir.

Hacıbekir Mahallesi'nden katılanların \%14,7'si, Ali Paşa Mahallesi'nden katılanların \%32'si ve Cumhuriyet Mahallesi'nden katılanların \%30,7'si evlerindeki en güvenilir yeri tespit ettiklerini söylemiştir. Deprem sigortası yaptırma oranlarına benzer şekilde, deprem anında evin güvenilir yerini belirleme konusunda da üst ve orta sosyoekonomik özelliklere sahip katılımcıların, düşük sosyoekonomik özellikteki katılımcılara oranla daha bilinçli oldukları gözlenmiştir. Bu da bize depremden korunmaya dönük bilinç düzeyi ile sosyoekonomik özellikler arasında doğru bir orantının olduğunu göstermektedir.

Depremde yapılması gerekenlere yönelik katılımcıların ön bilgilerini tespit etmeyi amaçlayan "Depremi yaşamadan önce olası bir deprem anında neler yapılması gerektiğiyle ilgili bir bilginiz var mıydı?" sorusuna Hacıbekir Mahallesi katılımcılarının \%14'ü, Ali Paşa Mahallesi katılımcılarının \%28'i ve Cumhuriyet Mahallesi katılımcılarının \%40'ı "Evet” yanıtını vermiştir. Söz konusu oranlar dikkate alındığında sosyoekonomik özellikler ile deprem esnasında nasıl davranılması gerektiğine dair bilgi sahibi olma konusunda anlamlı bir ilişkinin olduğu görülmektedir.

Son olarak katılımcılara yaşadıkları yerleşim yerinin deprem riski özellikleriyle ilgili olarak “2011 Depremleri öncesinde Van'ın deprem bölgesi olduğunu biliyor muydunuz?” sorusuna verilen yanıtlar incelenmiştir. Mahallere göre oranlar karşılaştırıldığında Cumhuriyet Mahallesi katılımcılarının \%30'u, Ali Paşa Mahallesi katılımcılarının \%34'ü ve Hacıbekir Mahallesi katılımcılarının \%58'inin Van'ın deprem bölgesi olduğunu bilmedikleri tespit edilmiştir. Tüm mahallelerde bu oran yüksek çıkmakla beraber benzer şekilde düşük sosyoekonomik özellikteki bireylerin orta ve yüksek sosyoekonomik düzeydeki bireylere oranla yaşadıkları kentin deprem özellikleri hakkında daha az bilgiye sahip oldukları gözlenmiştir.

\section{SONUÇ}

Türkiye'de toplumun her seferinde depremlere hazırlıksız yakalanması sürekli tartışılan bir konudur. Bunun altında sosyal, ekonomik ve kültürel birçok faktör olduğu düşünülmekle beraber toplumun depremleri anlamlandırma ve açıklama biçimlerinin risk azaltma süreçleri üzerindeki etkisinin ne düzeyde olduğunu tespit etmek üzere yapılmış bu çalışma, 2011 Van Depremleri'ne maruz kalmış bireylerin depremleri anlamlandırma, açıklama biçimleri ile risk azaltma süreçlerini, sosyoekonomik özellikleri etrafında değerlendirmiştir.

Elde edilen sonuçlara göre bireyler depremlerin neden olduğu yıkımları, can ve mal kayıplarını kader olarak görmektedirler. Katılımcıların büyük bir çoğunluğuna göre (\%88) tüm yaşanılanlar Allah'ın insanlara verdiği bir uyarıdır. Bu açıklamaya alt gelir grubunu oluşturan katılımcıların, üst ve orta gelir grubundakilere oranla daha fazla başvurdukları gözlenmiştir. Benzer şekilde katılımcıların yarısından fazlasına göre $(\% 67,5)$ depremlerin temel nedenlerinden birisi artan ahlaksızlıklardır. Mahallelerin temsil ettikleri sosyoekonomik özellikler dikkate alınarak oranlar yorumlandığında alt gelir grubundaki mahalle 
katılımcılarının orta ve üst gelir grubundakilere oranla bu tür açıklamalara daha çok başvurdukları gözlenmiştir. Depremi rasyonel süreçlerin dışında anlamlandıran ve açıklamalarında doğal süreçlerin dışında referans arayan katılımcılar depremlerle beraber dine yönelme oranları da artmıştır. Yapılan tespitlerde katılımcıların yarısından fazlası $(\% 56,5)$ depremlerin ardından kendisini daha dindar hissettiğini belirtmiştir. Sosyoekonomik açıdan bakıldığında yine benzer tablo oluşmaktadır. Düşük sosyoekonomik özellikteki katılımcılar, yüksek sosyoekonomik özellikteki katılımcılara oranla afet dönemlerinde dine daha fazla yönelmektedirler.

Depremi daha çok doğal olmayan süreçlerle açıklama eğiliminde olan düşük sosyoekonomik özellikteki grupların benzer şekilde üst ve orta gelir grubundakilere oranla risk azaltma oranları çok daha yetersizdir. Yapılan tespitlerde deprem sigortası yaptırma, deprem çantası hazırlama, deprem anında neler yapılması gerektiğine dair bilgi ile Van'ın deprem bölgesi olduğuna dair ön bilgililerin sosyoekonomik özelliklere göre değiştiği tespit edilmiştir. Nitekim düşük sosyoekonomik özellikteki katılımcıların deprem sigortası yaptırma başta olmak üzere, deprem çantası hazırlama konusunda üst ve orta gelir grubuna oranla geride kaldıkları gözlenmiştir. Benzer şekilde gelir düzeyi arttıkça kentin depremselliği hakkında ön bilgilere sahip olma ile deprem anında nasıl davranılması gerektiğine dair kritik bilgilere sahip olma oranında artış gözlenmektedir. Sonuç olarak bu araştırma ile düşük sosyoekonomik özellikteki katılımcıların depremleri doğal olmayan süreçlerle açıklama eğiliminin, orta ve üst sosyoekonomik özelliktekilere oranla daha fazla olduğu tespit edilmiştir. Yaşanan depremler bu bireyler için genellikle irrasyonel süreçlerdir. Dolayısıyla kaderine razı bireyler için depremlere hazırlık yapmak, önlem almak veya bir bütün olarak risk azaltmak çok da tercih edilen bir durum değildir.

\section{KAYNAKLAR}

AFAD. (2014). Türkiye'de Afet Farkındalığı ve Afetlere Hazırık Araştırması. www.afad.gov.tr. (21.03.2017).

Akyel, R. (2007). Afet yönetim sistemi: Türk Afet Yönetiminde Karşılaşılan Sorunların Tespit Ve Çözümüne İlişkin Bir Araştırma.(Yayınlanmamış Doktora Tezi), Çukurova Üniversitesi Sosyal Bilimler Enstitüsü, Adana.

Arslantaş, N. (2003). İslam dünyasında depremler ve algılanma biçimleri: ilk on asrında (h. IX/m. VII-XVI. yüzyıllar) (Vol. 50). İstanbul: Gelenek Yay.

Bilik, M.B. (2015). 2011 Van Depremleri Üzerine Sosyolojik Bir Analiz, Mekan, Afet Yönetimi ve Algı. (Yayınlanmamış Yüksek Lisans Tezi), Yüzüncü Yıl Üniversitesi, Sosyal Bilimler Enstitüsü, Van.

Duman, M. Z.(2016). Sosyolojik Açıdan Deprem ve Din, Depremlerin Dini Inanç ve Davranışlar Üzerindeki Etkisi. İstanbul: Rağbet Yay.

Dynes, R. R. (1999). The Dialogue between Voltaire and Rousseau on the Lisbon Earthquake: The Emergence of a Social Science View. International journal of mass emergencies and disasters, 18(1), 97-115.

Giddens, A. (1994). Modernliğin Sonuçları, Çev. Ersin Kuşdil, Ayrıntı Yay., İstanbul.

İBB. (2014). Afet Odaklı Sosyal Hasar Görebilirlik Analiz Sonuç Raporu. www.ibb.gov.tr. (16.03.2017). 
Karancı, A.N. (2008). Afet Zaralarını Azaltmada Psikolojinin Önemi, JICA Türkiye Ofisi, Yayın No: 2: 51-53.

Kasapoğlu, A. ve Ecevit, M.(2001). Depremin Sosyolojik Araştırması, Ankara: Sosyoloji Derneği Yayınları.

Koçak, H. (2004). Bir Doğal Afet Olarak Depreme Hazırlıklı Olma Bilinci ve Katılım: ABD, Japonya ve Türkiye (Afyon II Örneği), Yayınlanmamış Doktora Tezi. Ankara Üniversitesi, Sosyal Bilimler Enstitüsü, Ankara: 139.

Köse, A. ve Küçükcan, T. (2006). Deprem ve Din, İstanbul: Emre Yayınları.

Kula, N. (2002). Deprem ve Dini Başa Çıkma, Gazi Üniversitesi, Çorum Illahiyat Fakültesi Dergisi, 2002/l.

Müderrisoğlu, S. (2008). "Nitel ve Nicel Sonuçlar: Risk Algısı, Risk Azaltma ve Hazırlık Önlemleri”, İstanbul: Afet ve İnsan (içinde), Boğaziçi Üniversitesi Yayınevi, 81-124.

Spilka, B., Shaver, P., \& Kirkpatrick, L. A. (1985). A general attribution theory for the psychology of religion. Journal for the scientific study of religion, 1-20.

User, İ. (2006). "Düzce'ye Araba Çarptı": Depremin Psiko-sosyal Etkileri, Toplumbilim Dergisi, Deprem Özel Sayısı, Sayı 21, 2006, İstanbul, 39.

TBMM. (2010). Deprem Riskinin Araştırılarak Deprem Yönetiminde Alınması Gereken Önlemlerin Belirlenmesi Amacıyla Kurulan Meclis Araştırması Komisyonu İcin Hazırlanmış Rapor. 23. Dönem. S. Sayısı: 549.

Vercleyen, F. (1997). Bizans Döneminde İstanbul'da Depremler: Halk Üzerinde Etkisi (Çev: F. Ş. Arık). Tarih Araştırmaları Dergisi 30, 299-317. 